ISSN 0258-7122

Bangladesh J. Agril. Res. 33(3) : 631-638, December 2008

\title{
GENETIC ANALYSIS FOR PANICLE CHARACTERS IN DIALLEL CROSS OF RICE
}

\author{
K. M. IFTEKHARUDDAULA ${ }^{1}$, M. A. NEWAZ ${ }^{2}$, \\ M. A. SALAM ${ }^{3}$ AND KHALEDA AKTER ${ }^{4}$
}

\begin{abstract}
An experiment was carried out to study the genetic components for eight panicle characters in rice using an 8-parent half diallel cross excluding reciprocals during Transplant Aman season, 2003. The parental genotypes used in the study were BRRI dhan29, BR4828-54-4-l-4-9, BRR1 dhan28, 1R8, Amol3, 1R6561038-2-4-2-6-3, Minikit and ZhongYu7, which were chosen for their diversity in panicle characters. Hayman's analysis of variance (ANOVA) indicated importance of both additive and non-additive genetic components for all the panicle characters except dominance component for filled grains/secondary branches. The ANOVA showed unidirectional dominance for the characters viz, primary branch length, secondary branch length, primary branches/panicle, secondary branches/panicle and filled grains/primary branch, asymmetrical gene distribution for all the panicle traits except filled grains/secondary branch and residual dominance effects for all the panicle characters studied. Two out of eight panicle characters viz., primary branches/panicle and unfilled grains/ secondary branch followed the simple additive-dominance genetic model. The rest of the panicle characters showed nonallelic gene interaction or epistasis. According to $\mathrm{Vr}-\mathrm{Wr}$ graph, partial dominance was involved in the action of genes governing the inheritance of primary branches/panicle, while complete dominance was involved in the inheritance of unfilled grains/secondary branch. Most of the dominant genes for primary branches/panicle belonged to other hand, 1R8 possessed most of the dominant genes, while 1R65610-38-2-4-2-6-3 possessed most of the recessive genes for unfilled grains/secondary branch. The estimates of components of variance demonstrated involvement of both additive and dominant components in the inheritance of primary branches/panicle and unfilled grains/secondary branch. The distribution of dominant and recessive genes was unequal in the parents for these two characters also. There was drastic influence of environment on these two panicle characters following simple additive-dominance genetic model. Heritability in narrow sense ( $\left.\mathrm{h}^{2} \mathrm{~ns}\right)$ was very high for primary branches/panicle and unfilled grains/secondary branch.
\end{abstract}

Key Words: Genetic analysis, diallel cross, panicle characters, rice.

\footnotetext{
${ }^{1}$ Senior Scientific Officer, Plant Breeding Division, ${ }^{3}$ Chief Scientific Officer, Plant Breeding Division, ${ }^{4}$ Senior Scientific Officer, Genetic Resources and Seed Division, BRRI, Joydebpur, Gazipur-1701, 'Professor, Department of Genetics and Plant Breeding, BAU, Mymensingh-2202, Bangladesh.
} 


\section{Introduction}

Rice, the major crop of Bangladesh, constitutes $94.38 \%$ of the total food grain (rice and wheat) production accounting for 26.7 million metric tons (Anonymous, 2004). Rice is the staple food and ranks first position by production among cereals in Bangladesh. Bangladesh is the fourth largest producer and consumer of rice in the world with an annual production ranging from 25 to 26 million metric tons (Bhuiyan et al., 2002). The yield potential of current modem rice varieties in the tropics of Asia has stagnated recently. It is essential to improve the yield potential of modem rice varieties which can be accomplished through improving genetic potentiality of the genotypes. For another quantum jump in rice yield potential, we need to modify the present high yielding plant type. Panicle characters represent the most important part of rice plant type in respect of yield improvement. Bangladesh Rice Research Institute (BRRI) has so far developed a number of modem rice varieties suitable for different ecosystems. The yield potentials of these rice varieties vary due to the architecture of panicle. Yield increase in modem rice was possible through improvement of panicle characters viz, long panicles, high number of filled grains, more primary and secondary rachis, etc. (Seetharaman et al., 1973). Hence, apart from yield and its component characters, emphasis should be given on panicle characters. But improvement of panicle characters requires investigation on their genetic system. Information on mode of inheritance and nature of genetic components of panicle characters in rice are very scanty (Mahmood et al., 2004; Chang et al., 1998; Kim, 1987). More information is required on these aspects. The mode of inheritance of different characters can be investigated following Hayman's (I 954a and 1954b) variance component analysis in diallel crosses. The present investigation has been undertaken with an attempt to study the mode of inheritance and nature of genetic components of eight panicle characters in an eight-parent half-diallel cross of rice.

\section{Materials and Method}

Eight genotypes of rice viz., BRRI dhan29, BR4828-54-4-1-4-9, BRRI dhan28, 1R8, Amol3, 1R65610-38-2-4-2-6-3, Minikit and ZhongYu7 with different panicle characters were crossed in diallel fashion excluding reciprocals. Twentyeight $F_{1} s$ and their parents were grown in a randomized complete block design with three replications at the experimental farm of Bangladesh Rice Research Institute, Gazipur in Transplant Aman season, 2003. Twenty five days old seedlings were transplanted with single seedling/hill at the spacing of $25 \mathrm{~cm} \times$ $20 \mathrm{~cm}$. The unit plot size was $2 \mathrm{~m} \times 2$ rows. The recommended crop management for Transplant Aman season was followed. Observations on eight panicle traits were recorded from each replication. The lengths of primary and secondary branches of panicle were measured in $\mathrm{cm}$ from randomly selected panicles and 
average data were used. Similarly, number of primary and secondary branches per panicle, filled and unfilled grains per primary and secondary branches of the panicles were determined. The data were analyzed for analysis of variance and Vr-Wr graph following Hayman (1 954a) and Hayman (1 954b). Components of genetic parameters were calculated following numerical approach of Jinks and Hayman (1953) based on Mather’s notation (Mather and Jinks, 1982).

\section{Results and Discussion}

\section{Preliminary ANOVA}

The mean squares due to genotypes for all the panicle traits under present study were highly significant as shown by the preliminary ANOVA. The results indicated significant differences among 36 genotypes of the present diallel study, which was necessary for further analysis (Table 1). Genotypes were partitioned into parents $(\mathrm{P})$, crosses $\left(\mathrm{F}_{1}\right)$ and parents vs. crosses $\left(\mathrm{P}\right.$ vs. $\left.\mathrm{F}_{1}\right)$ items. All the panicle traits showed significant mean squares due to parents and crosses from which significant differences among parents and crosses separately were obtained. The parents vs. crosses item was significant for primary branch length, secondary branch length, primary branches per panicle, secondary branches per panicle and filled grains per primary branch which detected the presence of significant overall heterosis in cross combination for the concerned characters.

Table 1. Preliminary analysis of variance (MS) for different panicle traits in an 8parent diallel cross of rice

\begin{tabular}{|c|c|c|c|c|c|c|c|c|c|}
\hline Item & df & $\begin{array}{c}\text { Primary } \\
\text { branch } \\
\text { length } \\
(\mathrm{cm})\end{array}$ & $\begin{array}{c}\text { Secondary } \\
\text { branch } \\
\text { length }(\mathrm{cm})\end{array}$ & $\begin{array}{c}\text { Primary } \\
\text { branches/ } \\
\text { panicle }\end{array}$ & $\begin{array}{c}\text { Secondary } \\
\text { branches/ } \\
\text { panicle }\end{array}$ & $\begin{array}{c}\text { Filled } \\
\text { grains/ } \\
\text { primary } \\
\text { branch }\end{array}$ & $\begin{array}{c}\text { Unfille } \\
\text { grains/ } \\
\text { primary } \\
\text { branch }\end{array}$ & $\begin{array}{c}\text { Filled } \\
\text { grains/ } \\
\text { secondary } \\
\text { branch }\end{array}$ & $\begin{array}{c}\text { Unfilled } \\
\text { grains/ } \\
\text { secondary } \\
\text { branch }\end{array}$ \\
\hline Replication & 2 & 0.698 & 0.034 & 0.203 & 3.06 & 2.83 & 0.243 & 0.249 & 0.024 \\
\hline Genotype & 35 & $3.336 * * *$ & $0.248 * * *$ & $4.573 * * *$ & $168.55^{* * *}$ & $16.20 * * *$ & $\begin{array}{l}1.640 * * \\
*\end{array}$ & $0.225^{* *}$ & $0.086^{* * *}$ \\
\hline P (Parent) & 7 & $2.877 * * *$ & $0.187 * * *$ & $8.884 * * *$ & $87.70 * * *$ & $6.88 *$ & $1.926^{*}$ & $0.229 *$ & $0.099 * * *$ \\
\hline $\mathrm{F}_{1}$ & 27 & $3.012 * * *$ & $0.231^{* * *}$ & $3.479 * * *$ & $177.48^{* * *}$ & $18.08^{* * *}$ & $\begin{array}{l}1.609 * * \\
*\end{array}$ & $0.224 * *$ & $0.86^{* * *}$ \\
\hline$P$ vs. $F_{1}$ & 1 & $15.30 * * *$ & $1.134 * * *$ & $3.937 * *$ & $493.60 * * *$ & $30.87 * *$ & 0.467 & 0.240 & 0.000 \\
\hline Error & 70 & 0.316 & 0.030 & 0.416 & 19.20 & 3.08 & 0.243 & 0.104 & 0.019 \\
\hline
\end{tabular}

${ }^{*} \mathrm{p}<0.05 ; * * \mathrm{p}<0.01 ; * * * \mathrm{p}<0.001$ 


\section{Morley Jones ANOVA}

Highly significant mean squares due to the item a (additive component) and $\mathrm{b}$ (dominance component) were found for all the characters except for mean square due to ' $b$ ' for filled grains per secondary branch (Table 2). Hence, both additive and dominance genetic components were important in the inheritance of all the panicle traits except dominance component for filled grains/secondary branch. Significant item 'b' established the validity of further analysis of $\mathrm{Vr}-\mathrm{Wr}$ graph.

Table 2. Hayman analysis of variances (MS) following Morley Jones modification for different panicle traits in an 8-parent diallel cross of rice.

\begin{tabular}{l|c|c|c|c|c|c|c|c|c}
\hline Item & df & $\begin{array}{c}\text { Primary } \\
\text { branch } \\
\text { length } \\
(\mathrm{cm})\end{array}$ & $\begin{array}{c}\text { Secondary } \\
\text { branch } \\
\text { length }(\mathrm{cm})\end{array}$ & $\begin{array}{c}\text { Primary } \\
\text { branches/ } \\
\text { panicle }\end{array}$ & $\begin{array}{c}\text { Secondary } \\
\text { branches/ } \\
\text { panicle }\end{array}$ & $\begin{array}{c}\text { Filled } \\
\text { grains/ } \\
\text { primary } \\
\text { branch }\end{array}$ & $\begin{array}{c}\text { Unfille } \\
\text { grains/ } \\
\text { primary } \\
\text { branch }\end{array}$ & $\begin{array}{c}\text { Filled } \\
\text { grains/ } \\
\text { secondary } \\
\text { branch }\end{array}$ & $\begin{array}{c}\text { Unfilled } \\
\text { grains/ } \\
\text { secondary } \\
\text { branch }\end{array}$ \\
\hline a & 7 & $2.622^{* * *}$ & $0.222^{* * *}$ & $4.937 * * *$ & $114.04^{* * *}$ & $12.97^{* * *}$ & $1.037^{* * *}$ & $0.174^{* * *}$ & $0.055^{* * *}$ \\
$\mathrm{~b}$ & 28 & $0.734^{* * *}$ & $0.048^{* * *}$ & $0.671^{* * *}$ & $41.72^{* * *}$ & $3.51^{* * *}$ & $0.24^{* * *}$ & 0.050 & $0.022^{* * *}$ \\
$\mathrm{~B}_{1}$ & 1 & $5.100^{* * *}$ & $0.378^{* * *}$ & $1.312^{* *}$ & $164.53^{* * *}$ & $2.98^{* *}$ & 0.156 & 0.080 & 0.000 \\
$\mathrm{~B}_{2}$ & 7 & $0.608^{*}$ & $0.049^{* * *}$ & $0.446^{* *}$ & $28.38^{* * *}$ & $2.98^{*}$ & $0.555^{* * *}$ & 0.058 & $0.033^{* * *}$ \\
$\mathrm{~B}_{3}$ & 20 & $0.560^{* * *}$ & $0.031^{* * *}$ & $0.718^{* * *}$ & $40.25^{* * *}$ & $3.36 * * *$ & $0.391^{* * *}$ & 0.046 & $0.019^{* * *}$ \\
Error & 70 & 0.105 & 0.010 & 0.139 & 6.40 & 1.03 & 0.081 & 0.035 & 0.006 \\
\hline
\end{tabular}

${ }^{*} \mathrm{p}<0.05 ;{ }^{* *} \mathrm{p}<0.01 ;{ }^{* * *} \mathrm{p}<0.001$

Item $b_{1}$ was highly significant for primary branch length, secondary branch length, primary branches per panicle, secondary branches per panicle and filled grains per primary branch, which detected unidirectional dominance and significant differences between parental and hybrid grand mean for these five characters. Again, asymmetrical gene distribution was obtained for all the panicle traits expect filled grains per secondary branch as item $b_{2}$ was significant for the respective characters. Finally, item $b_{3}$, representing residual dominance effects, was significant for all the studied panicle traits indicating the involvement of the part of dominance deviation which did not belong to $b_{1}$ and $b_{2}$. The significant $b_{3}$ also showed dominance effects specific to individual crosses (Mather and Jinks, 1982).

\section{Vr-Wr graph}

Statistics related to Vr-Wr analysis showed that out of eight panicle traits, only two traits (primary branches per panicle and unfilled grains per secondary branch) satisfied the assumptions related to the simple additive-dominance genetic model (Table 3). The rest of the panicle traits exhibited nonallelic gene interaction or epistasis. Kim (1987) obtained nonallelic gene interactions for all 
the panicle traits he studied. While Chang et al. (1998) reported epistasis for number of primary branches per panicle and number of spikelets per panicle, but they explained the inheritance of primary branch length using the additivedominance genetic model. The Vr-Wr graph and Hayman's numerical approach have been, therefore, subjected for primary branches per panicle and unfilled grains per secondary branch only.

Tabele 3. Statistics related to $\mathrm{Vr}-\mathrm{Wr}$ analysis for different panicle traits in an 8-parent diallel cross of rice.

\begin{tabular}{l|r|r|r|r|r|r|r}
\hline \multicolumn{1}{c}{ Character } & $\mathrm{a}$ & $\mathrm{b}$ & $\mathrm{SE}(\mathrm{b})$ & $\mathrm{b}=1$ & $\mathrm{~b}=0$ & $\mathrm{t}^{2}$ & Significance of $\mathrm{t}^{2}$ \\
\hline $\begin{array}{l}\text { Primary branch } \\
\text { length (cm) }\end{array}$ & 0.114 & 0.313 & 0.200 & $*$ & $\mathrm{~ns}$ & 2.72 & $\mathrm{~ns}$ \\
$\begin{array}{l}\text { Secondary branch } \\
\text { length (cm) }\end{array}$ & 0.015 & 0.248 & 0.258 & $*$ & $\mathrm{~ns}$ & 1.093 & $\mathrm{~ns}$ \\
$\begin{array}{l}\text { Primary branch/ } \\
\text { panicle }\end{array}$ & 0.1912 & 0.845 & 0.262 & $\mathrm{~ns}$ & $*$ & 0.058 & $\mathrm{~ns}$ \\
$\begin{array}{l}\text { Secondary branch/ } \\
\text { panicle }\end{array}$ & -3.728 & 0.361 & 0.146 & $* *$ & $\mathrm{~ns}$ & 6.45 & $*$ \\
$\begin{array}{l}\text { Filled grains/ primary } \\
\text { branch }\end{array}$ & 2.665 & -0.250 & 0.155 & $* *$ & $\mathrm{~ns}$ & 6.57 & $*$ \\
$\begin{array}{l}\text { Unfilled } \\
\text { grains/primary branch }\end{array}$ & -0.111 & 0.530 & 0.268 & $\mathrm{~ns}$ & $\mathrm{~ns}$ & 0.288 & $\mathrm{~ns}$ \\
$\begin{array}{l}\text { Filled grains/ } \\
\text { secocondary }\end{array}$ & -0.0010 & 0.411 & 0.278 & $\mathrm{~ns}$ & $\mathrm{~ns}$ & 0.435 & $\mathrm{~ns}$ \\
$\begin{array}{l}\text { Unfilled grains/ } \\
\text { secondary branch }\end{array}$ & -0.012 & 0.733 & 0.275 & $\mathrm{~ns}$ & $*$ & 0.000 & $\mathrm{~ns}$ \\
\hline
\end{tabular}

The regression line for primary branches per panicle intercepted Wr-axis above the origin with the ' $a$ ' value of 0.1912 indicates partial dominance in the inheritance of primary branches per panicle (Fig. 1). For unfilled grains per secondary branch, the regression line seemed to intercept below the origin (Fig. 2). This was because of too smaller values of $\mathrm{Vr}$ and Wr. Actually, on the basis of the value ' $a$ ' for this character $(-0.012)$, more or less complete dominance could be considered for unfilled grains per secondary branch. The position of the array point for BRRI dhan 29 was nearest to the origin, which implicated that most of the dominant genes for primary branches per panicle belonged to BRRI dhan29. On the other hand, Amol3 contained most of the recessive genes for the same character as array point for Amol3 was placed farthest from the origin. On the same background, 1R8 possessed the most of the dominant genes, while 1R65610-38-2-4-2-6-3 possessed most of the recessive genes for unfilled grains per secondary branch.

\section{Components of variance}

The estimates of components of variance reflected that both additive (D) and dominance variance $\left(\mathrm{H}_{1}\right.$ and $\left.\mathrm{h}_{2}\right)$ were all highly significant (Table 4$)$ for primary 
branches per panicle and unfilled grains/secondary branch. The results indicated the importance of both additive and non-additive genetic variance in the inheritance of these two characters. Mahmood et al. (2004) reported that additive genetic effects were important for the expression of variation of number of primary branches per panicle in an 8-parent diallel cross of rice.

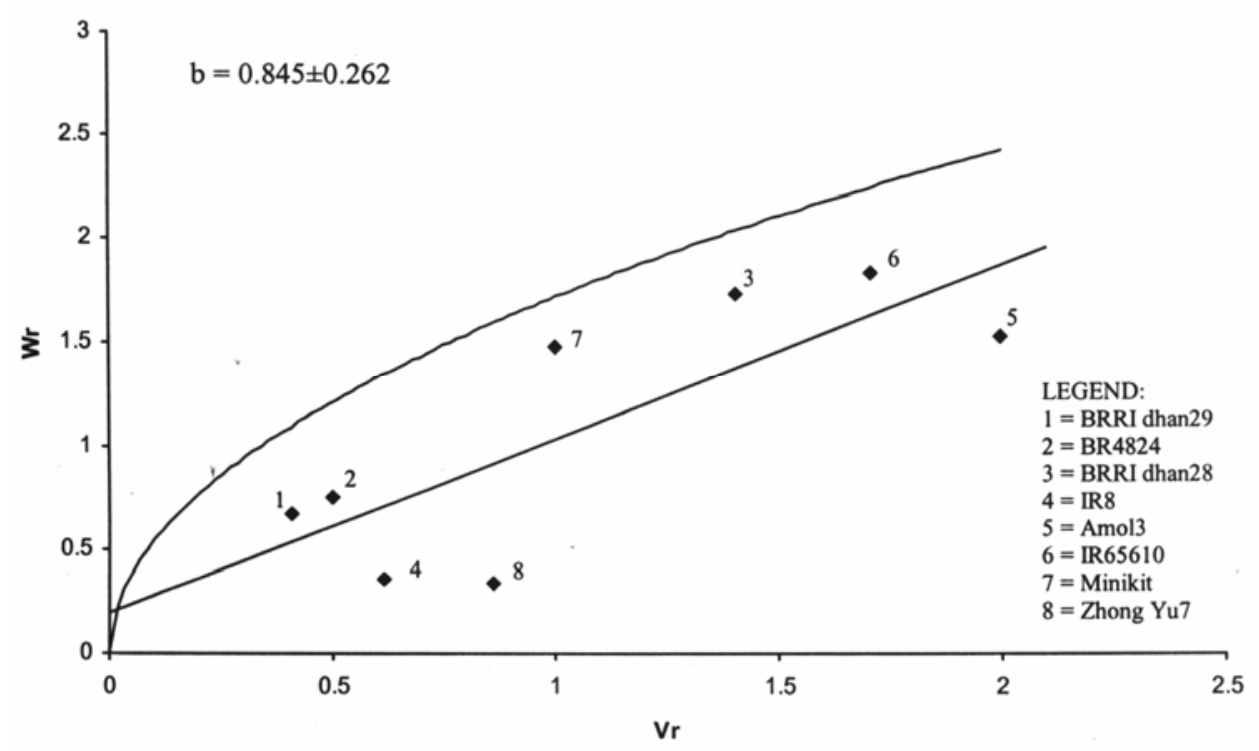

Fig 1. Vr-Wr graph for primary branch/ panicle

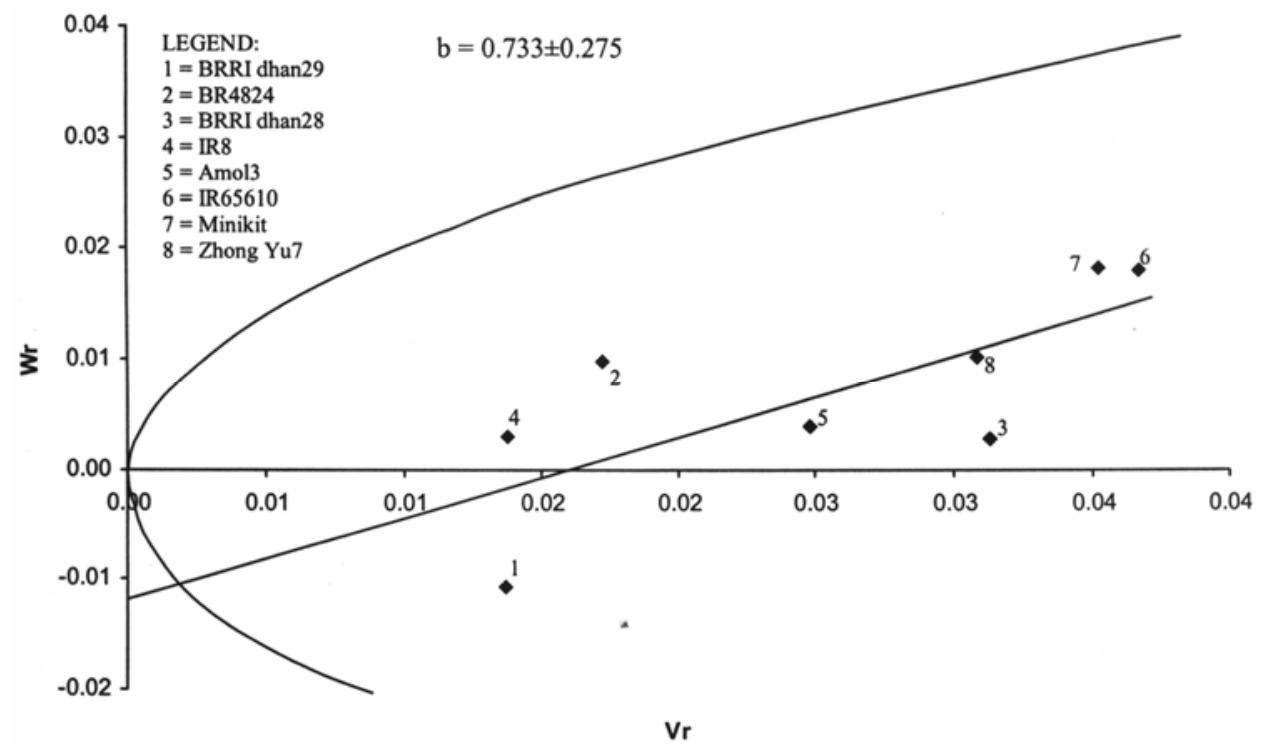

Fig 2. Vr-Wr graoh for unfilled grains/ secondary branch 
Table 4. Components of variance and genetic parameters for panicle characters in an 8-parent diallel cross of rice.

\begin{tabular}{|c|c|c|}
\hline Components & Primary branch number & $\begin{array}{l}\text { Unfilled grains/ } \\
\text { secondary branch }\end{array}$ \\
\hline $\mathrm{E}$ & $0.137 * * * \pm 0.0005$ & $0.00065^{* * *} \pm 0.00001$ \\
\hline $\mathrm{D}$ & $2.82 * * * \pm 0.0016$ & $0.0266^{* * * \pm 0.00003}$ \\
\hline $\mathrm{F}$ & $1.36^{* * *} \pm 0.0038$ & $0.0290 * * * \pm 0.00007$ \\
\hline $\mathrm{H}_{1}$ & $2.13 * * * \pm 0.0032$ & $0.0631^{* * * \pm 0.00007}$ \\
\hline $\mathrm{H}_{2}$ & $2.16 * * * \pm 0.0032$ & $0.0631^{* * * \pm 0.00006}$ \\
\hline$h^{2}$ & $1.55^{* * *} \pm 0.0021$ & $-0.0202 * * * \pm 0.00004$ \\
\hline$\sqrt{D / H_{1}}$ & 0.121 & 0.707 \\
\hline$H_{2} / 4 H_{1}$ & 12.99 & 1.18 \\
\hline$\sqrt{4 D H_{1}}+F$ & 3.03 & 7.69 \\
\hline$\sqrt{4 D H_{1}}-F$ & & \\
\hline$r_{x y}$ & $-0.858 * *$ & 0.118 \\
\hline$r^{2}$ & 0.737 & 0.014 \\
\hline $\mathrm{h}^{2} / \mathrm{H}_{2}$ & 0.716 & 0.320 \\
\hline $\mathrm{h}_{\mathrm{nn}}^{2}$ & 0.978 & 0.18 \\
\hline
\end{tabular}

${ }^{*} \mathrm{p}<0.05 ;{ }^{* *} \mathrm{p}<0.01 ; * * * \mathrm{p}<0.001$

Inequality of the two components $\mathrm{H}_{1}$ and $\mathrm{H}_{2}$ for primary branches per panicle and unfilled grains per secondary branch indicated unequal distribution of positive and negative alleles in the parents for these two characters. These findings were further established by the $\mathrm{H}_{2} / 4 \mathrm{H}_{1}$ ratio being highly deviated from 0.25 . Significant $\mathrm{h}_{2}$ indicated net dominance effect for all loci which was 1.55 and -0.0202 for primary branches per panicle and unfilled grains per secondary branch, respectively. The mean degree of dominance $\left(\sqrt{ } \mathrm{H}_{1} / \mathrm{D}\right)$ was less than unity for primary branches per panicle indicating partial dominance. The same value for unfilled grains per secondary branch could be taken as unity indicating complete dominance.

The influence of environment on two panicle traits was drastic as the component E was significant for these two characters. Primary branches per panicle and unfilled grains per secondary branch showed positive sign for the 
component $\mathrm{F}$ which meant that dominant alleles were more frequent than recessive alleles in the parents for the two characters. The results were confirmed by the ratio $\left(\sqrt{4 \mathrm{DH}_{1}}+\mathrm{F}\right)\left(\sqrt{4 \mathrm{DH}_{1}}-\mathrm{F}\right)$ which were greater than unity for the respective traits.

The correlation coefficient (r) between parental measurement (Yr) and parental order of dominance $(\mathrm{Wr}+\mathrm{Vr}$ ) was highly significant and negative indicating recessive alleles to have positive effects for primary branches per panicle. Again, positive correlation coefficient for unfilled grains per secondary branch in the present study revealed that the parents containing most decreasing genes had the lowest values of $\mathrm{Wr},+\mathrm{Vr}$, and thus decreasing genes were prevalent in them (Singh and Chaudhary, 1985). The prediction of completely dominant and recessive parents were not possible, which was revealed from less than unity $r^{2}$ estimates for the two panicle traits in rice.

Number of blocks of dominant genes was estimated from $\mathrm{h}^{2} / \mathrm{H}_{2}$ ratios, which were 0.716 and 0.320 for primary branches per panicle and unfilled grains per secondary branch, respectively. The narrow sense heritability was very high for these two characters.

\section{References}

Annonymous. 2004. Bangladesh Arthanaitic Sameekhkha, Ministry of Finance, Government of the People's Republic of Bangladesh.

Bhuiyan, N. I., D. N. R. Paul and M. A. Jabber. 2002. Feeding the extra millions by 2025- challenges for rice research and extension in Bangladesh. A keynote paper presented on national workshop on rice research and extension 2002. Held on 29-3 1 January, 2002, BRRJ. p. 9.

Chang, J. K., B. G. Oh, H. Y. Kim, S. J. Lim, S. C. Kim and J. K. Sohn. 1998. Genetic analysis of traits associated with panicle and flag leaf in tropical japonica rice. Korean J. of Crop Sci. 43(3): 135-140.

Hayman, B. J. 1954a. The analysis of variance of diallel table. Biometrics. 10: 235-244.

Hayman, B. J. 1954b. The theory and analysis of diallel crosses. Genetics 39: 789-809.

Jinks, J. L. and B. I. Hayman. 1953. The analysis of diallel crosses. Maize Genet. Crop. News Letter 27: 48-54.

Kim, Z. H. 1987. Genetic analysis of six panicle characters in rice. Korean I Crop Sci. 32(2): 208-214.

Mahmood, T. M. Turner, F. L. Stoddard and M A. Javed. 2004. Genetic analysis of quantitative traits in rice (Oryza sativa L.) exposed to salinity. Australian-Journalof-Agricultural- Research. 55(11): 1173-1181.

Mather, K. and J. L. Jinks. 1982. Biometrical Genetics. Chapman and Hall, New York.

Seetharaman, R., D. P. Srivastava, M. K. Sinha. 1973. Studies in rice genetic stock. Indian I Genet. Pt. Breed. 33(3): 362-368.

Singh, R. K. and B. D. Chaudhary. 1985. Biometrical Methods in Quantitative Genetic Analysis. Kalyani Publishers, New Delhi. 